\title{
AMBULATORINIŲ PACIENTŲ SVEIKATOS RAŠTINGUMO IR VIDINĖS DARNOS SĄSAJOS
}

\author{
Jonas Sąlyga ${ }^{1,2}$, Laimutė Kazlauskienè ${ }^{1,2}$, Geriuldas Žiliukas ${ }^{1,2}$, Dovilė Majauskyte் ${ }^{3}$ \\ ${ }^{1}$ Klaipèdos universitetas, ${ }^{2}$ Klaipédos jürininku ligonine, ${ }^{3}$ Vilniaus universitetas
}

Raktažodžiai: sveikatos raštingumas, vidinè darna, ambulatoriniai pacientai.

\begin{abstract}
Santrauka
Tyrimo tikslas. Nustatyti ambulatorinių pacientų sveikatos raštingumo ir vidinès darnos sąsajas bei ryšị su sociodemografiniais rodikliais.

Tyrimo metodika. Tyrime naudoti metodai: sveikatos raštingumo (SR) vertinimui - Europos SR klausimynas (HLS - EU - Q47). Vidinès darnos (VD) A. Antonovsky sutrumpintas gyvenimo orientacijos klausimynas (SOC - 13). SR, VD ir demografiniu duomenų priežastiniams ryšiams nustatyti taikyta daugialypè tiesinès regresijos analizè. Pasirenkant priklausomus ir nepriklausomus kintamuosius sudaryti atskiri tiesinès regresijos modeliai. Imtị sudarè 201 ambulatorinis pacientas. Iš jų 122 moterys ir 79 vyrai. Amžius nuo 18 - 88 metų. Duomenys statistiškai apdoroti. Tyrimas atliktas laikantis etikos principų. Tyrimo rezultatai. Nustatyta, kad daugumos pacientu SR buvo nepakankamas. Geriausiai savo SR pacientai vertino sveikatos priežiūros srityje, blogiausiai sveikatos stiprinimo srityje. Pacientų aktualios sveikatos informacijos supratimas buvo žymiai geresnis nei gavimas, ịvertinimas ir pritaikymas. Informacijos pritaikymas buvo žymiai blogesnis nei jos supratimas ir îvertinimas. Pacientų VD buvo vidutinè. Teigiami ryšiai nustatyti tarp bendro $S R$, visų jo sričių ir bendros VD ir visų VD komponenčių. Stipriausi ryšiai $(p<0,001)$ nustatyti tarp VD prasmingumo jausmo ir bendro SR ir SR sveikatos stiprinimo srityje. Aukštesniam pacientų SR visose srityse ịtakos turèjo stipresnè VD, jos prasmingumo komponentè ir jaunesnis tiriamujų amžius. SR sveikatos priežiūros srityje - aukštesnis išsilavinimas; ligų prevencijos srityje moteriška lytis. Bendrą VD stiprino aukštesnis bendras SR, SR sveikatos stiprinimo ir sveikatos priežiūros srityse, vyresnis pacientų amžius, aukštesnis
\end{abstract}

išsilavinimas ir darbo turejjimas. VD suprantamumo jausmą stiprino vyriška lytis, aukštesnis išsilavinimas ir darbo turèjimas; kontrolès jausmą - vyresnis amžius ir aukštesnis išsilavinimas; prasmingumo aukštesnis SR sveikatos stiprinimo srityje ir aukštesnis išsilavinimas.

Išvada. Aukštesniam pacientų SR įtakos turèjo stipresnè VD, VD prasmingumo komponente, jaunesnis pacientų amžius ir aukštesnis išsilavinimas. Stipresnei pacientų VD ir jos komponentèms ịtakos turèjo aukštesnis bendras SR, SR sveikatos stiprinimo ir sveikatos priežiūros srityse, vyresnis amžius, aukštesnis išsilavinimas ir darbo turèjimas. Siekiant pagerinti pacientų SR, tikslinga stiprinti VD ir jos suprantamumo, kontrolès, prasmingumo komponentes; organizuojant SR mokymus atsižvelgti ị išsilavinimą ir amžių.

\section{Ivadas}

Gera gyventojų sveikata yra vienas svarbiausių šalies išsivystymo požymių. Pagal Pasaulio sveikatos organizacijos (PSO) sveikatos strategiją „Sveikata 2020“ - sveikata yra ne tik ligos ar negalios nebuvimas, bet ir psichinè bei socialiné gerovè. Todèl siekiama investuoti ị socialinius sveikatos gerovę skatinančius veiksnius - sveikatos stiprinimą ir ligu prevenciją [2]. Europos sveikatos priežiūros (SP) politikos formuotojai, mokslininkai ir specialistai vis daugiau dèmesio skiria sveikatos koncepcijos tobulinimui, tačiau žinių apie sveikatos raštingumą (SR) Europoje dar vis trūksta [10].

Keičiantis SP teisinei sistemai, gausejjant sveikatos informacijai, labai svarbūs kognityviniai ịgūdžiai ir patikimi informacijos šaltiniai, nes apgaulinga informacija sukelia problemų raštingiausiems piliečiams [14]. Lietuvoje ir užsienyje atliktų tyrimų rezultatai rodo, kad 47 proc. Europos gyventojų yra nepakankamo SR, beveik pusei būna sunku suprasti SP specialistų patarimus, trečdaliui - televizijos ir radijo laidas [5]. Pakankamo SR asmenys yra reiklesni sveikatos informacijai [13]. Žemesnis SR lemia blogesnę sveikatos būklę ir didesnį SP paslaugų poreikị. Finansinis 
nepriteklius, socialinè padetis, išsilavinimas, amžius ir lytis - pagrindinès priežastys turinčios ịtakos SR [10]. Tačiau ne mažiau svarbi ir psichoemocinè savijauta. Vienas iš ją sąlygojančių veiksnių yra vidinè darna (VD). Tai vidinė žmogaus orientacija, besireiškianti pozityviais jo santykiais su pačiu savimi ir pasauliu. Pagal (A. Antonovsky 1979) salutogenezès teoriją, žmogus turi bendruosius atsparumo išteklius, kurie padeda įveikti sunkumus ir ligas. Nustatyta, jog sergančiųjų lètinèmis ligomis VD yra silpnesnè nei sveikujų. Asmenys su žemesne VD turi didesnį rizikos laipsni susirgti,dažniau patiria fizinị smurtą, stokoja esminių socialinių igūdžių, rečiau linkę keisti gyvenseną bei rūpintis savo sveikata. Silpną VD Lietuvoje turejo 55 proc. gyventojų, kai tuo tarpu Švedijoje - 19 proc. [7, 3]. Tam įtakos turi ne tik socialiniai, ekonominiai veiksniai, bet ir fizinès, psichinès priežastys $[8,9]$. Su VD susijusi ir ES šalių problema depresija bei savižudybès. Dideli psichoemocinio susijaudinimo priepuoliai, jei asmuo nesugeba jų valdyti, gali sukelti pavojų gyvybei, ịvykti staigi mirtis [9].

Pastaruoju metu stebimas didesnis susidomejjimas SR tema, daugiau dèmesio skiriama psichologinèms problemoms ir VD reikšmei. Tačiau atliktų tyrimų šia tema Lietuvoje nèra daug. Atlikus mokslinių šaltinių analizę, tyrimų, kuriuose būtų analizuojamos SR ir VD sąsajos, aptikti nepavyko.

Tyrimo tikslas: nustatyti ambulatorinių pacientų sveikatos raštingumo ir vidinès darnos sąsajas bei ryšị su sociodemografiniais duomenimis.

\section{Tyrimo medžiaga ir metodai}

Tyrimas atliktas vienoje $\mathrm{X}$ miesto gydymo įstaigoje. Buvo apklausiami pacientai, atvykę ambulatorinès gydytojų specialistų konsultacijos, sutikę dalyvauti tyrime ir neturintys medicininio išsilavinimo. Tiriamajị kontingentą sudarè 201 ambulatorinis pacientas, nuo 18 iki 88 metų (amžiaus vidurkis $50,3 \pm 14,0 \mathrm{~m}$.) - iš jų 122 (60,7 proc.) buvo moterys ir 79 (39,3 proc.) vyrai. Daugiau nei puse (52,2 proc.) tiriamuju buvo 30-54 metu, 30,3 proc. $-55-69$ metu, 9, 0 proc. -70 metu ir vyresni, 8,5 proc. $-18-29$ metų. Dauguma (41,8 proc.) tiriamųjų turèjo aukštajį išsilavinimą, 22,9 proc. aukštesnijji, 29,9 proc. - vidurinị/spec.vidurinị ir 5,5 proc. pradini/pagrindinį. Pagal gyvenamą vietą 78,6 proc. tiriamujų buvo miesto, 10,0 proc. - mažesnių miestelių ir 11,4 proc. - kaimo gyventojai. Pagal socialinę padètị daugumą (72,1 proc.) sudare dirbantys asmenys, 15,9 proc. tiriamujų buvo pensininkai, 6,0 proc. - bedarbiai, 2,0 proc. - moksleiviai/ studentai ir 4,0 proc. - kiti (nurodè neigalumą). Pagal šeimyninę padèti dauguma $(65,7$ proc.) tiriamujų buvo vedę $\backslash$ ištekejjusios, 7,0 proc. - gyveno nesusituokę, 10,9 proc. - buvo nevedę $\backslash$ netekejjusios, 8,5 proc. - išsiskyrę $\backslash$ išsituokusios ir 8,0 proc. - našliailnašlès.
Siekiant iqvertinti SR ir VD buvo taikomas kiekybinis tyrimas, naudota anketinė apklausa raštu. Tyrimo anketa sudaryta remiantis Europos SR klausimynu (HLS - EU-Q - 47) ir A. Antonovsky sutrumpintu gyvenimo orientacijos klausimynu (SOC - 13). Gautas leidimas jomis naudotis. SR buvo vertinamas pagal tris sritis (duomenis): sveikatos priežiūros, ligų prevencijos, sveikatos stiprinimo ir keturis aktualios informacijos apdorojimo etapus - gauti, suprasti, ivertinti ir pritaikyti. Buvo apskaičiuoti bendro SR ir visu jo sričių indeksai, kurių reikšmè galëjo būti nuo 0 iki 50 balų, didesnis skaičius reiškè aukštesnị SR. VD vertinta pagal tris komponentes: suprantamumo, prasmingumo ir kontrolès. VD klausimyno (SOC - 13) 1-3; 5-6; 8-13 klausimų atsakymai buvo reversuojami. Apskaičiuoti standartizuoti VD ir jos komponenčių (suprantamumo, prasmingumo ir kontrolès jausmų) rodikliai, kurių reikšmè galejjo būti nuo 1 iki 7 balų, didesnis skaičius reiškè stipresnę VD. Gauti duomenys buvo susisteminti ir grafiškai pavaizduoti. Aprašomoji duomenų analizė atlikta statistiniu programų paketu „,SPSS 17.0.1 for Windows". Analizuojant koreliacinius imties požymių ryšius naudotas Pirsono (Pearson) (r) koreliacijos metodas. $\mathrm{SR}, \mathrm{VD}$ ir demografinių duomenų priežastiniams ryšiams nustatyti taikyta daugialype tiesinès regresijos analizè. Siekiant išvengti multikolinearumo (stiprių koreliacinių ryšių) problemos, buvo ịvertinti SR sričių tarpusavio ryšiai bei VD komponenčių tarpusavio ryšiai. Tarp bendros VD ir jos komponenčių nustatyti labai stiprūs ryšiai $(r=[0,83-0,93])$, todèl analizuojant VD įtaką SR buvo sudaryti skirtingi regresiniai modeliai įtraukiant bendrą VD rodikli, o paskui atskirų VD komponenčių rodiklius. Tarp bendro SR ir jo sričių taip pat nustatyti labai stiprūs ryšiai $(\mathrm{r}=[0,89-0,90])$, todèl nagrinejjant SR įtaką VD buvo sudaryti atskiri regresiniai modeliai įtraukiant bendrą SR indeksą, o paskui visų SR sričių indeksus. VD, jos komponenčių ir demografinių duomenų itaka bendram SR ir SR visose srityse, buvo vertinta pagal daugialypès tiesinès regresijos modelius. Pasirenkant priklausomus ir nepriklausomus kintamuosius buvo sudaryti atskiri tiesinès regresijos modeliai. Naudoti statistinių hipotezių reikšmingumo lygmenys: kai $p<0,05$ - reikšminga (*); kai $\mathrm{p}<0,01$ - labai reikšminga (**); kai $\mathrm{p}<0,001$ - itin reikšminga $(* * *)$, kai $\mathrm{p}>0,05$ (ns) - statistiškai nereikšminga. Klausimynų patikimumas apskaičiuotas pagal Kronbacho (Cronbach) alfa. Atliekant tyrimą buvo laikomasi etikos principų.

\section{Tyrimo rezultatai}

Ambulatorinių pacientụ sveikatos raštingumas. Vertinant SR buvo apskaičiuoti visų SR sričių indeksai: bendro SR indeksas sudare (30,2 $\pm 6,0$ balų); SR SP srityje

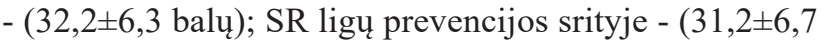




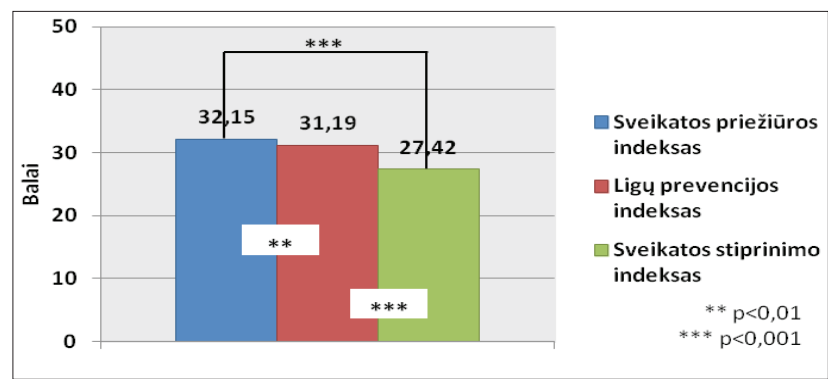

1 paveikslas. Sveikatos raštingumo indeksai pagal sritis.

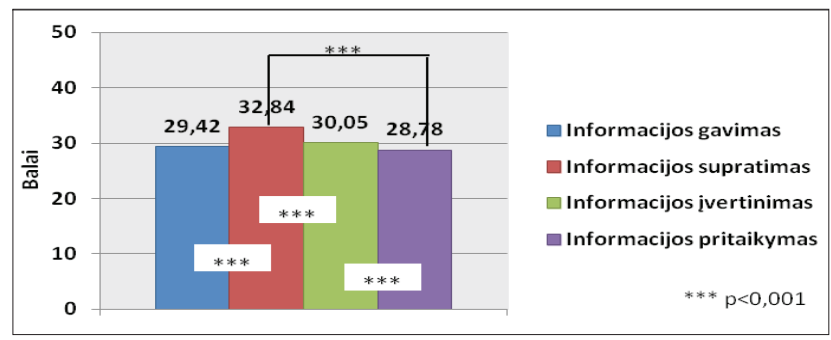

2 paveikslas. Aktualios sveikatos informacijos apdorojimo etapu vertinimas.

balų) ir SR sveikatos stiprinimo

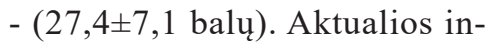
formacijos apdorojimo etapų indeksai - gavimo sudare $(29,4 \pm 7,5$ balų), supratimo $(32,8 \pm 6,5$ balų), ivvertinimo $(30,1 \pm 6,7$ balų) ir pritaikymo $(28,8 \pm 6,1$ balų). Visų indeksų reikšmès gautos šiek tiek didesnès už vidutinę galimą reikšmę ( 25 balai) (1 pav.).

Nustatyta, kad tiriamieji geriausiai savo SR vertino SP srityje $(p<0,01)$, o blogiausiai, sveikatos stiprinimo srityje $(\mathrm{p}<0,001)$. (1 pav.)

Sveikatos raštingumo vertinimas pagal aktualios informacijos apdorojimo etapus. Tyrimo rezultatai parodè, kad tiriamieji žymiai geriau vertino informacijos supratimą, nei jos gavimą, ìvertinimą ir pritaikymą $(\mathrm{p}<0,001)$. Informacijos pritaikymą žymiai blogiau vertino, nei jos supratimą ir ịvertinimą ( $<<0,001)$ (2 pav.).

Pacientų vidinė darna. Bendroje tiriamujų grupeje bendrą VD rodiklio vidurki sudare $4,8 \pm 0,8$ sritimis. raštingumui. koeficientas, turi büti mažesnis už 4 .

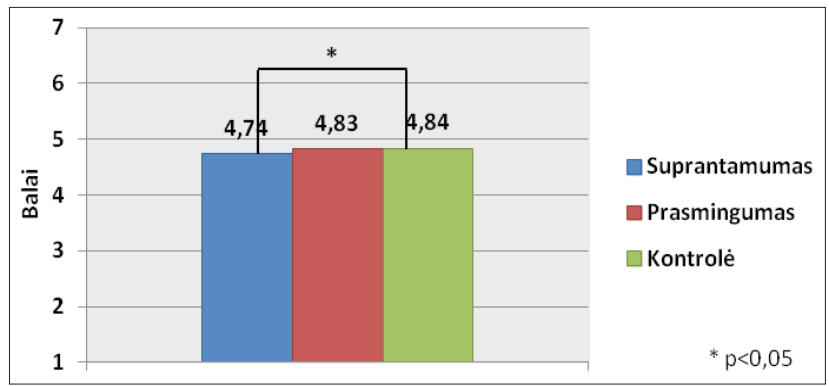

3 paveikslas. Vidinès darnos komponenčių vertinimas.

balų, suprantamumo jausmo- $4,7 \pm 0,9$, prasmingumo jausmo $-4,8 \pm 0,9$ balų ir kontrolès jausmo $-4,8 \pm 0,9$ balų.

Nustatyta, kad tiriamieji VD kontrolès jausmą vertino reikšmingai geriau nei VD suprantamumo jausmą. (3 pav.).

Sveikatos raštingumo sričių, vidinès darnos ir jos komponenčių bei sociodemografinių duomenų sąsajos. Bendroje tiriamujų grupejje nustatyti itin reikšmingi $(p<0,001)$ teigiami ryšiai tarp visų SR sričiu , bendros VD ir jos komponenčių $(r=[0,27-0,48] \mathrm{p}<0,001)$. Tiriamieji su

1 lentelè. Pacientų vidinès darnos ir komponenčių sąsajos su sveikatos raštingumo

\begin{tabular}{|l|c|c|c|c|c|c|c|c|}
\hline \multirow{2}{*}{ SR sritys } & \multicolumn{2}{|c|}{$\begin{array}{c}\text { Suprantamu- } \\
\text { mas }\end{array}$} & \multicolumn{2}{|c|}{ Kontrolé } & \multicolumn{2}{|c|}{$\begin{array}{c}\text { Prasmingu- } \\
\text { mas }\end{array}$} & \multicolumn{2}{c|}{$\begin{array}{c}\text { Bendra } \\
\text { vidine } \\
\text { darna }\end{array}$} \\
\cline { 2 - 10 } & $\mathbf{r}$ & $\mathbf{p}$ & $\mathbf{r}$ & $\mathbf{p}$ & $\mathbf{r}$ & $\mathbf{P}$ & $\mathbf{r}$ & $\mathbf{p}$ \\
\hline $\begin{array}{l}\text { Bendras sveikatos } \\
\text { raštingumas }\end{array}$ & 0,33 & $<0,001$ & 0,34 & $<0,001$ & $\mathbf{0 , 4 8}$ & $<\mathbf{0 , 0 0 1}$ & 0,42 & $<0,001$ \\
\hline Sveikatos priežiūra & 0,32 & $<0,001$ & 0,35 & $<0,001$ & 0,43 & $<0,001$ & 0,41 & $<0,001$ \\
\hline Ligų prevencija & 0,29 & $<0,001$ & 0,27 & $<0,001$ & 0,37 & $<0,001$ & 0,35 & $<0,001$ \\
\hline Sveikatos stiprinimas & 0,27 & $<0,001$ & 0,30 & $<0,001$ & $\mathbf{0 , 4 8}$ & $<\mathbf{0 , 0 0 1}$ & 0,39 & $<0,001$ \\
\hline
\end{tabular}

2 lentelè. Sociodemografinių rodiklių ir bendros vidinès darnos įtaka pacientų sveikatos

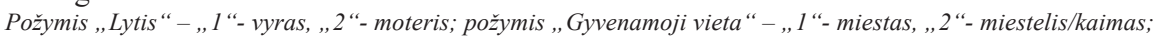
požymis ,Darbinè padètis - „, I“- dirbantis, ,,2“-nedirbantis; ns-nereikšmingas ryšis; VIF-multikolinearumo

\begin{tabular}{|c|c|c|c|c|c|c|c|c|}
\hline \multirow{3}{*}{$\begin{array}{l}\text { Priklausomas } \\
\text { kintamasis } \\
\text { Nepriklausomi } \\
\text { kintamieji }\end{array}$} & \multirow{2}{*}{\multicolumn{2}{|c|}{$\begin{array}{l}\text { Modelis } 1 \\
\text { Bendras } \\
\text { sveikatos } \\
\text { raštingumas } \\
\end{array}$}} & \multirow{2}{*}{\multicolumn{2}{|c|}{\begin{tabular}{|l|} 
Modelis 2 \\
$\begin{array}{l}\text { Sveikatos } \\
\text { priežiūra }\end{array}$
\end{tabular}}} & \multirow{2}{*}{\multicolumn{2}{|c|}{$\begin{array}{l}\text { Modelis } 3 \\
\text { Ligụ } \\
\text { prevencija }\end{array}$}} & \multirow{2}{*}{\multicolumn{2}{|c|}{$\begin{array}{l}\text { Modelis } 4 \\
\text { Sveikatos } \\
\text { stiprinimas }\end{array}$}} \\
\hline & & & & & & & & \\
\hline & $\beta$ & p & $\beta$ & $\mathbf{p}$ & $\beta$ & $\mathbf{P}$ & $\beta$ & p \\
\hline Lytis & 0,12 & ns & 0,11 & ns & 0,15 & 0,029 & 0,06 & ns \\
\hline Amžius & $-0,15$ & 0,038 & $-0,09$ & ns & $-0,09$ & ns & $-0,21$ & 0,004 \\
\hline Išsilavinimas & 0,11 & ns & 0,15 & 0,034 & 0,05 & ns & 0,10 & ns \\
\hline Gyvenamoji vieta & $-0,05$ & ns & $-0,09$ & ns & $-0,07$ & ns & 0,01 & ns \\
\hline Darbinè padètis & 0,02 & ns & 0,01 & ns & $-0,07$ & ns & 0,09 & ns \\
\hline Bendra vidinè darna & 0,40 & $<0,001$ & 0,37 & $<0,001$ & 0,32 & $<0,001$ & 0,38 & $<0,001$ \\
\hline $\mathrm{R}_{\text {adi }}^{2}(\mathrm{p})$ & \multicolumn{2}{|c|}{$0,21(<0,001)$} & \multicolumn{2}{|c|}{$0,20(<0,001)$} & \multicolumn{2}{|c|}{$0,14(<0,001)$} & \multicolumn{2}{|c|}{$0,20(<0,001)$} \\
\hline VIF & \multicolumn{2}{|c|}{$1,05-1,25$} & \multicolumn{2}{|c|}{$1,05-1,25$} & \multicolumn{2}{|c|}{$1,05-1,25$} & \multicolumn{2}{|c|}{$1,05-1,25$} \\
\hline
\end{tabular}


stipresne VD turèjo aukštesni SR, nei tiriamieji su silpnesne VD. Stipriausi ryšiai nustatyti tarp vidinès darnos prasmingumo jausmo komponentès ir bendro $\mathrm{SR}(\mathrm{r}=0,48 \mathrm{p}<0,001)$ ir ypač su SR susijusiu su sveikatos stiprinimu ( $\mathrm{r}=0,48$ $\mathrm{p}<0,001)$ (1 lentelè).

Nustatyta, kad bendram SR didžiausią ịtaką turejo stipresnè bendra $\operatorname{VD}(\beta=0,40, p<0,001)$ ir jaunesnis tiriamujų amžius $(\beta=-0,15, p=0,038)$. SR susijusiam su SP sritimi didžiausią įtaką turèjo stipresnė bendra $\operatorname{VD}(\beta=0,37, p<0,001)$ ir aukštesnis tiriamujų išsilavinimas $(\beta=0,15, p=0,034)$. SR

3 lentelè. Sociodemografinių duomenų ir vidinès darnos komponenčių ịtaka pacientų sveikatos raštingumui.

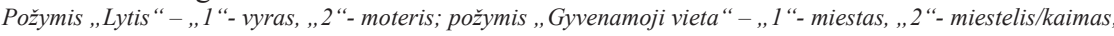
požymis „Darbine padètis - „1“"-dirbantis, „,2“- nedirbantis; ns-nereikšmingas ryšis; VIF-multikolinearumo koeficientas, turi būti mažesnis už 4 .

\begin{tabular}{|c|c|c|c|c|c|c|c|c|}
\hline \multirow{3}{*}{$\begin{array}{l}\text { Priklausomas kintama- } \\
\text { sis } \\
\text { Nepriklausomi kinta- } \\
\text { mieji }\end{array}$} & \multirow{2}{*}{\multicolumn{2}{|c|}{$\begin{array}{c}\text { Modelis 5 } \\
\text { Bendras } \\
\text { sveikatos } \\
\text { raštingumas }\end{array}$}} & \multirow{2}{*}{\multicolumn{2}{|c|}{$\begin{array}{l}\text { Modelis 6 } \\
\text { Sveikatos } \\
\text { priežiūra }\end{array}$}} & \multirow{2}{*}{\multicolumn{2}{|c|}{$\begin{array}{c}\text { Modelis } 7 \\
\text { Ligų } \\
\text { prevencija }\end{array}$}} & \multirow{2}{*}{\multicolumn{2}{|c|}{$\begin{array}{c}\text { Modelis } 8 \\
\text { Sveikatos } \\
\text { stiprinimas }\end{array}$}} \\
\hline & & & & & & & & \\
\hline & $\beta$ & p & $\beta$ & $\mathbf{p}$ & $\beta$ & $\mathbf{P}$ & $\beta$ & p \\
\hline Lytis & 0,09 & ns & 0,09 & ns & 0,13 & ns & 0,02 & ns \\
\hline Amžius & $-0,13$ & ns & $-0,08$ & ns & $-0,07$ & $\mathrm{~ns}$ & $-0,20$ & 0,006 \\
\hline Išsilav & 0,10 & ns & 0,14 & 0,043 & 0,04 & ns & 0,08 & ns \\
\hline Gyvenamoji vieta & $-0,06$ & ns & $-0,09$ & ns & $-0,08$ & ns & $-0,01$ & ns \\
\hline Darb & 0,01 & ns & $-0,01$ & ns & $-0,07$ & ns & 0,08 & ns \\
\hline Suprantamumas & $-0,02$ & ns & $-0,04$ & ns & 0,09 & ns & $-0,10$ & ns \\
\hline Kontrolè & 0,11 & ns & 0,16 & ns & 0,02 & ns & 0,10 & ns \\
\hline Prasmin & 0,39 & $<0,001$ & 0,31 & $<0,001$ & 0,26 & 0,003 & 0,46 & $<0,001$ \\
\hline $\mathrm{R}^{2}(\mathrm{p})$ & \multicolumn{2}{|c|}{$0,24(<0,001)$} & \multicolumn{2}{|c|}{$0,22(<0,001)$} & \multicolumn{2}{|c|}{$0,15(<0,001)$} & \multicolumn{2}{|c|}{$0,24(<0,001)$} \\
\hline VIF & \multicolumn{2}{|c|}{$1,07-3,24$} & \multicolumn{2}{|c|}{$1,07-3,24$} & \multicolumn{2}{|c|}{$1,07-3,24$} & \multicolumn{2}{|c|}{$1,07-3,24$} \\
\hline
\end{tabular}

4 lentelè. Sociodemografinių rodiklių ir sveikatos raštingumo įtaka pacientų vidinei darnai ir komponentèms.

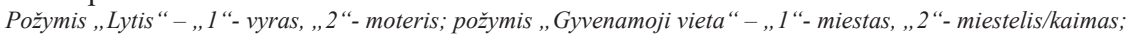
požymis „,Darbine padètis - „1“- dirbantis, ,,2“- nedirbantis; ns-nereikšmingas ryšis; VIF-multikolinearumo koeficientas, turi būti mažesnis už 4 .

\begin{tabular}{|c|c|c|c|c|c|c|c|c|}
\hline \multirow{3}{*}{$\begin{array}{l}\text { Priklausomas kinta- } \\
\text { masis } \\
\text { Nepriklausomi kinta- } \\
\text { mieji }\end{array}$} & \multirow{2}{*}{\multicolumn{2}{|c|}{$\begin{array}{c}\text { Modelis 1 } \\
\text { Bendra } \\
\text { vidinė } \\
\text { darna }\end{array}$}} & \multicolumn{2}{|c|}{ Modelis 2} & \multicolumn{2}{|c|}{ Modelis 3} & \multicolumn{2}{|c|}{ Modelis 4} \\
\hline & & & \multicolumn{2}{|c|}{$\begin{array}{l}\text { Suprantamu- } \\
\text { mas }\end{array}$} & \multicolumn{2}{|c|}{ Kontrolė } & \multicolumn{2}{|c|}{$\begin{array}{l}\text { Prasmingu- } \\
\text { mas }\end{array}$} \\
\hline & $\beta$ & $\mathbf{p}$ & $\beta$ & $\mathbf{p}$ & $\beta$ & p & $\beta$ & p \\
\hline Lytis & $-0,11$ & $\mathrm{~ns}$ & $\begin{array}{c}-0,14 \\
\end{array}$ & 0,035 & $-0,12$ & $\mathrm{~ns}$ & \begin{tabular}{|c|}
$-0,02$ \\
\end{tabular} & ns \\
\hline Amživ & 0,14 & 0,039 & 0,12 & ns & 0,19 & 0,010 & 0,08 & ns \\
\hline Išsilavinimas & 0,18 & 0,009 & 0,17 & 0,018 & 0,15 & 0,036 & 0,16 & 0,019 \\
\hline Gyvenamoji vieta & $-0,01$ & ns & $-0,02$ & ns & $-0,04$ & ns & 0,04 & ns \\
\hline Darbinè padètis & $-0,14$ & 0,044 & $-0,15$ & 0,037 & $-0,13$ & ns & $-0,09$ & ns \\
\hline $\begin{array}{l}\text { Bendras sveikatos raštin- } \\
\text { gumas }\end{array}$ & 0,39 & $<0,001$ & 0,30 & $<0,001$ & 0,32 & $<0,001$ & 0,44 & $<0,001$ \\
\hline $\mathrm{R}_{\text {adj }}^{2}(\mathrm{p})$ & \multicolumn{2}{|c|}{$0,22(<0,001)$} & \multicolumn{2}{|c|}{$0,15(<0,001)$} & \multicolumn{2}{|c|}{$0,16(<0,001)$} & \multicolumn{2}{|c|}{$0,24(<0,001)$} \\
\hline VIF & \multicolumn{2}{|c|}{$1,05-1,25$} & \multicolumn{2}{|c|}{$1,05-1,25$} & \multicolumn{2}{|c|}{$1,05-1,25$} & \multicolumn{2}{|c|}{$1,05-1,25$} \\
\hline
\end{tabular}

ligų prevencijos srityje didžiausią įtaką turèjo stipresnè bendra $\operatorname{VD}(\beta=0,32, p<0,001)$ ir moteriška lytis $(\beta=0,15$, $\mathrm{p}=0,029)$. SR sveikatos stiprinimo srityje didžiausią ịtaką turejo stipresnè bendra $\operatorname{VD}(\beta=0,38, \mathrm{p}<0,001)$ ir jaunesnis tiriamujju amžius $(\beta=-0,21, p=0,004)$ (2 lentelè).

Nustatyta, kad bendram aukštesniam SR įtakos turëjo tik stipresnis VD prasmingumo jausmas $(\beta=0,39, \mathrm{p}<0,001)$. Aukštesniam SR susijusiam su SP sritimi įtakos turejo stipresnis VD prasmingumo jausmas $(\beta=0,31, p<0,001)$ ir aukštesnis tiriamuju išsilavinimas $(\beta=0,14, p=0,043)$. (3 lentelè). Aukštesniam SR ligų prevencijos srityje, iš analizuojamų nepriklausomų kintamujju ịtakos turejo tik stipresnis VD prasmingumo jausmas $(\beta=0,26$, $\mathrm{p}=0,003)$. SR sveikatos stiprinimo srityje didžiausią įtaką turèjo stipresnis VD prasmingumo jausmas $(\beta=0,46$, $\mathrm{p}<0,001)$ ir jaunesnis tiriamujų amžius $(\beta=-0,20, p=0,006)$. ( 3 lentelè).

Nustatyta, kad stipresnei VD didžiausią ịtaką turèjo aukštesnis bendras SR $(\beta=0,39, p<0,001)$, vyresnis tiriamųjų amžius $(\beta=0,14$, $\mathrm{p}=0,039$ ), aukštesnis išsilavinimas $(\beta=0,18, p=0,009)$ ir darbo turejjimas $(\beta=-0,14, p=0,044)$. Stipresniam VD suprantamumo jausmui didžiausią ittaką turejjo aukštesnis bendras SR $(\beta=0,30, p<0,001)$, vyriška lytis $(\beta=-$ $0,14, p=0,035)$, aukštesnis išsilavinimas $(\beta=0,17, p=0,034)$ ir darbo turèjimas $(\beta=-0,15, p=0,037)$. Stipresniam kontrolès jausmui didžiausią įtaką turejo aukštesnis bendras $\mathrm{SR}(\beta=0,32$, $p<0,001)$, vyresnis amžius $(\beta=0,19$, $\mathrm{p}=0,010)$ ir aukštesnis išsilavinimas $(\beta=0,15, p=0,036)$. Stipresniam VD prasmingumo jausmui didžiausią ittaką turejjo aukštesnis bendras SR $(\beta=0,44, p<0,001)$ ir aukštesnis išsilavinimas $(\beta=0,16, p=0,019)$ (4 lentelè).

Nustatyta, kad stipresnei bendrai VD įtakos turejo aukštesnis SR sveikatos stiprinimo srityje $(\beta=0,23$, $\mathrm{p}=0,015)$ ir SP srityje $(\beta=0,21$, $\mathrm{p}=0,048)$. Taip pat VD stiprino vyresnis tiriamųjų amžius $(\beta=0,15$, $p=0,031)$, aukštesnis išsilavinimas $(\beta=0,17, p=0,016)$ ir darbo turèjimas $(\beta=-0,15, p=0,029)$. VD supran- 
tamumo jausmą stiprino vyriška lytis ( $\beta=-0,14, p=0,037)$, aukštesnis išsilavinimas $(\beta=0,17, p=0,023)$ ir darbo turéjimas $(\beta=-0,15, p=0,041)$. VD kontrolès jausmą stiprino vyresnis tiriamujų amžius $(\beta=0,19, p=0,010)$ ir aukštesnis išsilavinimas $(\beta=0,24, p=0,029)$. Stipresniam VD prasmingumo jausmui stipriausią ịtaką turejo aukštesnis SR sveikatos stiprinimo srityje $(\beta=0,38, p<0,001)$ ir aukštesnis tiriamujų išsilavinimas $(\beta=0,14, p=0,034)$ (5 lentelè).

Apibendrinant gautus rezultatus galima teigti, kad ambulatorinių pacientu bendrą VD stiprina aukštesnis SR sveikatos stiprinimo ir SP srityse. VD suprantamumo ir kontrolès jausmą stiprina aukštesnis bendras SR; VD prasmingumo jausmą stiprina aukštesnis SR sveikatos stiprinimo srityje.

\section{Rezultatų aptarimas}

Bendroje tiriamujju grupeje nustatyti itin reikšmingi ryšiai tarp SR ir jo visų sričių, VD ir jos visų komponenčių. Pacientai su stipresne VD turèjo aukštesnị SR, nei tiriamieji su silpnesne VD. Stipriausi ryšiai nustatyti tarp VD prasmingumo ir bendro SR, ir ypač su SR sveikatos stiprinimo srityje. Aukštesniam SR didžiausią įtaką turèjo stipresnè VD ir jaunesnis tiriamujų amžius. SR sveikatos priežiūros srityje - stipresne VD ir aukštesnis tiriamujų išsilavinimas; SR ligų prevencijos srityje - bendra VD ir moteriška lytis; SR sveikatos stiprinimo srityje - stipresne VD ir jaunesnis tiriamujų amžius. Panašūs rezultatai gauti ir anksčiau atliktuose SR tyrimuose [5, 10]. Bendram SR ịtakos turèjo tik stipresnis VD prasmingumo jausmas. Aukštesniam SR sveikatos priežiūros ir sveikatos stiprinimo srityse - stipresnis VD prasmingumo jausmas ir jaunesnis tiriamuju amžius; SR ligu prevencijos srityje - stipresnis VD prasmingumo jausmas. Apibendrinant gautus rezultatus galima daryti prielaidą, kad ambulatorinių pacientų aukštesniam SR visose srityse įtakos turi stipresnis VD prasmingumo jausmas ir
5 lentelè. Sociodemografinių rodiklių ir sveikatos raštingumo sričių įtaka pacientų vidinei darnai ir jos komponentems.

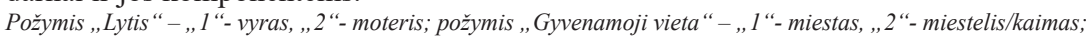
požymis ,,Darbiné padètis - ,, I"- dirbantis, ,,2“- nedirbantis; ns - nereikšmingas ryšis; VIF-multikolinearumo koeficientas, turi būti mažesnis už 4.

\begin{tabular}{|c|c|c|c|c|c|c|c|c|}
\hline \multirow{3}{*}{$\begin{array}{l}\text { Priklausomas kinta- } \\
\text { masis } \\
\text { Nepriklausomi kinta- } \\
\text { mieji }\end{array}$} & \multirow{2}{*}{\multicolumn{2}{|c|}{$\begin{array}{c}\text { Modelis } 5 \\
\text { Bendra } \\
\text { vidinė } \\
\text { darna }\end{array}$}} & \multirow{2}{*}{\multicolumn{2}{|c|}{$\begin{array}{c}\text { Modelis } 6 \\
\begin{array}{c}\text { Supranta- } \\
\text { mumas }\end{array}\end{array}$}} & \multirow{2}{*}{\multicolumn{2}{|c|}{$\begin{array}{l}\text { Modelis } 7 \\
\text { Kontrolė }\end{array}$}} & \multirow{2}{*}{\multicolumn{2}{|c|}{$\begin{array}{c}\text { Modelis } 8 \\
\begin{array}{c}\text { Prasmingu- } \\
\text { mas }\end{array}\end{array}$}} \\
\hline & & & & & & & & \\
\hline & $\beta$ & $\mathbf{p}$ & $\beta$ & $\mathbf{p}$ & $\beta$ & p & $\beta$ & $\mathbf{p}$ \\
\hline Lytis & $-0,10$ & ns & $-0,14$ & 0,037 & $-0,11$ & ns & $-0,01$ & ns \\
\hline Amžius & 0,15 & 0,031 & 0,12 & ns & 0,19 & 0,010 & 0,11 & ns \\
\hline Išsilavinimas & 0,17 & 0,016 & 0,17 & 0,023 & 0,13 & ns & 0,14 & $\mathbf{0 , 0 3 4}$ \\
\hline Gyvenamoji vieta & $-0,01$ & ns & $-0,02$ & ns & $-0,04$ & ns & 0,03 & ns \\
\hline Darbinè padètis & $-0,15$ & 0,029 & $-0,15$ & 0,041 & $-0,14$ & ns & $-0,12$ & ns \\
\hline Sveikatos priežiūra & 0,21 & 0,048 & 0,15 & ns & 0,24 & 0,029 & 0,18 & ns \\
\hline Ligų prevencija & 0,01 & ns & 0,08 & ns & $-0,04$ & ns & $-0,06$ & ns \\
\hline Sveikatos stiprinimas & 0,23 & 0,015 & 0,10 & ns & 0,16 & ns & 0,38 & $<0,001$ \\
\hline $\mathrm{R}_{\text {adj }}^{2}(\mathrm{p})$ & \multicolumn{2}{|c|}{$0,22(<0,001)$} & \multicolumn{2}{|c|}{$0,15(<0,001)$} & \multicolumn{2}{|c|}{$0,16(<0,001)$} & \multicolumn{2}{|c|}{$0,26(<0,001)$} \\
\hline VIF & \multicolumn{2}{|c|}{$1,06-2,87$} & \multicolumn{2}{|c|}{$1,06-2,87$} & \multicolumn{2}{|c|}{$1,06-2,87$} & \multicolumn{2}{|c|}{$1,06-2,87$} \\
\hline
\end{tabular}

jaunesnis amžius. Stipresnei VD didžiausią įtaką turèjo aukštesnis SR, vyresnis tiriamųų amžius, aukštesnis išsilavinimas ir darbo turèjimas; VD suprantamumo jausmui - aukštesnis SR, vyriška lytis, aukštesnis išsilavinimas ir darbo turèjimas; VD kontrolès jausmui - aukštesnis SR, vyresnis amžius ir aukštesnis išsilavinimas; VD prasmingumo jausmui - aukštesnis SR ir aukštesnis išsilavinimas. Kitų tyrèjų $[12,11]$ rezultatai rodo, jog stipresnę VD turèjo jaunesnio amžiaus, aukštesnio išsilavinimo, dirbantys ir vyriškos lyties respondentai. Šiame tyrime vyriška lytis didesnę įtaką turèjo tik VD prasmingumo jausmui. Ambulatorinių pacientų VD, jos suprantamumo, kontrolès, prasmingumo jausmų komponentes stiprina aukštesnis jų SR. Stipresnei VD įtakos turėjo aukštesnis SR sveikatos stiprinimo ir SP srityse, vyresnis tiriamųjų amžius, aukštesnis išsilavinimas ir darbo turejjimas; VD suprantamumo jausmui - vyriška lytis, aukštesnis išsilavinimas ir darbo turejjimas; VD kontrolès jausmui - vyresnis amžius ir aukštesnis išsilavinimas; VD prasmingumo jausmui - aukštesnis SR sveikatos stiprinimo srityje ir aukštesnis išsilavinimas.

\section{Išvados}

1. Ambulatoriniai pacientai savo sveikatos raštingumą geriausiai vertino sveikatos priežiūros, vidutiniškai - ligų prevencijos, blogiausiai - sveikatos stiprinimo srityje $(\mathrm{p}<0,001)$. Pagal aktualios informacijos apdorojomo etapus: informacijos supratimą vertino geriau, nei jos gavimą, įvertinimą ir pritaikymą. Informacijos pritaikymą vertino žymiai blogiau nei jos supratimą ir įvertinimą $(\mathrm{p}<0,001)$.

2. Aukštesniam sveikatos raštingumui visose srityse ịtakos turèjo stiprèsnè vidine darna ir jos prasmingumo jausmo komponentė; sveikatos priežiūros srityje - aukštesnis išsilavinimas; ligų prevencijos srityje - moteriška lytis; sveikatos stiprinimo srityje - jaunesnis amžius. Bendrą pacientų vidinę darną stiprino: aukštesnis sveikatos raštingumas sveikatos stiprinimo ir sveikatos priežiūros srityse; aukštesnis išsilavinimas; vyresnis pacientų amžius ir darbo 
turëjimas; prasmingumo jausmą - aukštesnis sveikatos raštingumas sveikatos stiprinimo srityje.

3. Ambulatorinių pacientų bendra vidinè darna buvo vidutinè. Kontrolès jausmo komponentè buvo reikšmingai geresnè nei suprantamumo. Visas vidinès darnos komponentes stiprino aukštesnis išsilavinimas; suprantamumą - vyriška lytis ir darbo turèjimas; kontrolę - vyresnis amžius.

4. Siekiant pagerinti pacientų sveikatos raštingumą, tikslinga stiprinti vidinę darną ir jos suprantamumo, kontrolès, prasmingumo komponentes; organizuojant sveikatos raštingumo mokymus atsižvelgti ị išsilavinimą ir amžių.

\section{Literatūra}

1. Antonovsky A. 1987.Unraveling the mystery of health. How people manage stress and stay well. San Francisco: Jossey-Bass.

2. JakabZ., TsaurosA., D.,,Sveikata2020“-siekiamesveikatosirvystymosi dabartinejje Europoje. Visuomenès sveikata, 2013; 4(63).

3. Javtokas Z. Sveikatos stiprinimo konspektas, 2009. Publikuota internete: http://vasc.sam.lt/lektūra.

4. Javtokas Z. 2012 Lietuvos gyventojų sveikatos raštingumo tyrimo duomenų apžvalga. LR SAM Sveikatos mokymo ir ligų centras. Vilniaus universiteto medicinos fakulteto visuomenės sveikatos institutas. Vilnius, 2012.

5. Javtokas Z., Sabaliauskas R. ir kt. Suaugusių Lietuvos gyventojų sveikatos raštingumas. Visuomenès sveikata, 2013; 4(63).

6. Javtokas Z., Žagminas K. Gyventojų sveikatos raštingumo vertinimas. Metodiniai patarimai. Sveikatos mokymo ir ligų precencijos centras, Vilniaus universiteto Medicinos fakulteto Sveikatos mokslų institutas, 2017.

7. Malinauskas R., Malinauskienė V., Dumčienė A., Šniras Š. Rizikos grupès vaikų esminiai socialiniai igūdžiai ir vidinė darna. Sveikatos mokslai, 2008; 5

8. Manganello JA. Health literacy and adolescents: a framework and agenda for future research. Health Education Research, 2008; 23(5):840-847. https://doi.org/10.1093/her/cym069

9. Petrulionienė Ž. 2018 Psichosocialiniai rizikos veiksniai ir širdies ligos:kaip padeti pacientui. Internistas, 2018; 2(179).

10. Sørensen K, Pelikan JM, Röthlin F, Ganahl K, Slonska Z, Doyle G, Brand H. Health literacy in Europe: comparative results of the European health literacy survey (HLS-EU). The European Journal of Public Health 2015; 25(6), 1053-1058. Prieiga per internetą: http://doi.org/10.1093/eurpub/ckv043

https://doi.org/10.1093/eurpub/ckv043

11. Stankūnas M, Kalèdienė R, Starkuvienė S. Vidinè darna ir jos sąsajos su psichosocialine sveikata. Medicina, Kaunas, 2009; 45(10):807.

https://doi.org/10.3390/medicina45100105

12. Stukas R., Šurkienė G., Žagminas K., Alekna V., Melvidaite A. Pagyvenusių žmonių vidinė darna. Gerontologija, 2012; 13(1): 3-11. 2013; 14(3): 131-140.

13. Zagurskienė D., Misevičienė I. Skirtingų sveikatos raštingumo lygių pacientų nuomonė apie slaugytojų teikiamą sveikatos informaciją. Medicina, Kaunas, 2010; 46(1):27-34.

14. Zagurskienė D. Pacientų sveikatos raštingumo vertinimas. Daktaro disertacija. Biomedicinos mokslai. Kaunas, 2009.

\section{THE CONNECTIONS BETWEEN HEALTH LITERA- CY AND HARMONY OF OUTPATIENTS}

J.Sąlyga, L.Kazlauskienė, G.Žiliukas, D.Majauskytė

Key words: health literacy, harmony, outpatients.

Summary

Aim of Research. Define the link between outpatients' health literacy and harmony, and its connection with sociodemographic indexes.

Methods of Research. This research is based on these methods: to define health literacy Europe's health literacy questionnaire was used (HSL - EU - Q47). To define harmony A. Antonovsky's concise questionnaire of life orientation was used (SOC - 13). To determine the connection between health literacy, harmony and demographic data multifaceted legal regression analysis was applied. While choosing dependent and independent variables different legal regression models were formed. Respondents were 201 outpatients. There were 122 women and 79 men. Age varied from 18 to 88 years old. Data was statistically edited. The research was conducted applying ethical standards.

Results of Research. It was detected that many of the patients had inadequate health literacy. Patients thought that they are the best at health supervision and the worst at health improving. $\mathrm{Pa}-$ tients' understanding of urgent health information was far better than its receipt, evaluation and application. Information application was far worse than its understanding and evaluation. Patients' harmony was average. Positive links were found between general health literacy and all of its areas and general harmony and all of the harmony components. The strongest links $(p<0,001)$ were detected between meaningfulness of harmony and general health literacy as well as the aspect of health promotion. Better harmony and its meaningfulness aspect as well as younger respondents' age had the influence on higher health literacy. Higher education had the influence on the aspect of health promotion, female gender had the influence on the aspect of disease prevention. General harmony was improved by higher general health literacy, health promotion and health supervision as well as older age of the patients, higher education and employment. The feeling of understanding harmony was improved by male gender, higher education and employment; the feeling of control was improved by older age and higher education; the feeling of meaningfulness was improved by the aspect of health promotion and higher education.

Conclusion. The influence for the higher health literacy of patients had better harmony, its aspect of meaningfulness, younger age and higher education. The influence for better harmony and its components had higher general health literacy, areas of health promotion and health supervision, older age, higher education and employment. In order to improve health literacy it is expedient to improve harmony and its components of understanding, control, meaningfulness. While organizing health literacy training it is important to pay attention to education and age of the participants.

Correspondence to: kazlauskiene.laimute@gmail.com

Gauta 2018-09-18 